TITLE:

\title{
RECORD OF AN ASCIDIAN FOUND ATTACHED TO A HOLOTHURIAN, PSEUDOSTICHOPUS SP
}

AUTHOR(S):

Tokioka, Takasi; Nishikawa, Teruaki

CITATION:

Tokioka, Takasi ...[et al]. RECORD OF AN ASCIDIAN FOUND ATTACHED TO A HOLOTHURIAN, PSEUDOSTICHOPUS SP. PUBLICATIONS OF THE SETO MARINE BIOLOGICAL LABORATORY 1977, 24(1-3): 23-26

ISSUE DATE:

1977-11-30

URL:

http://hdl.handle.net/2433/175964

RIGHT: 


\title{
RECORD OF AN ASCIDIAN FOUND ATTACHED TO A HOLOTHURIAN, PSEUDOSTICHOPUS SP. ${ }^{1)}$
}

\author{
TAkasi TOKIOKA and Teruaki NISHIKAWA
}

Seto Marine Biological Laboratory

With Text-figure 1

Though Molgula manhattensis (de Kay) is known to occur on the siphon of the bivalve, Mya arenaria L., it has rarely been reported that any ascidians are found attached to the living body wall of some animals other than certain simple ascidians, which is extensile and contractile even a little (Millar 1971, p. 40). So far as we are aware, the attachment of a small ascidian to the holothurian, Pseudostichopus mollis Théel, is the only example of such cases; Théel mentioned as "The surface of the skin is covered with small Ascidians, Sponges, Bryozoa, \&c., which have grown on it" (p. 170, lines 22-23).

Recently a small specimen of Styela was presented to us from Mr. Tohru Imaoka who found it on the lateral wall around the middle of a $205 \mathrm{~mm}$ long $\times 61 \mathrm{~mm}$ wide individual of Pseudostichopus sp., which was collected together with three other individuals from 400 to $450 \mathrm{~m}$ deep sand-muddy floor $15 \mathrm{~km}$ SE off Teuti of Koshikizima Island off the middle of the west coast of Kyusyu Island on October 27, 1976. These holothurians were generally incrusted with sand grains, foraminiferan shells and glass spicules of sponges, especially densely in the ventral half, and there small colonies of a kind of zoanthid were found attached rather commonly. In addition, some bryozoans, brachiopods, gastropods and mussels were found attached, too.

Close examination revealed that this ascidian resembled closely Styela atlantica (Van Name), but showing some differences. Some of differences might be taken as being of a specific significance. At present, however, we have come to the conclusion that the specimen is probably a minor form of Styela atlantica adapted to the special substratum mentioned above. The following descriptions are given as the basis for such a consideration.

The whole body is roughly triangular (fig. 1, a), $17 \mathrm{~mm}$ long and $10 \mathrm{~mm}$ high, flattened and wholly encrusted with fine sand, grains in the periphery are larger than those in the central portion. Siphons are practically indiscernible. The concavity for the body proper is oval (fig. 1, b), $10 \mathrm{~mm}$ long and $6 \mathrm{~mm}$ wide. The test is gelatinous, rather hard and impregnated with sand grains; it is extremely thin over the body proper on the side of attachment.

1) Contributions from the Seto Marine Biological Laboratory, No. 639.

Publ. Seto Mar. Biol. Lab., XXIV (1/3), 23-26, 1977.

(Article 3) 

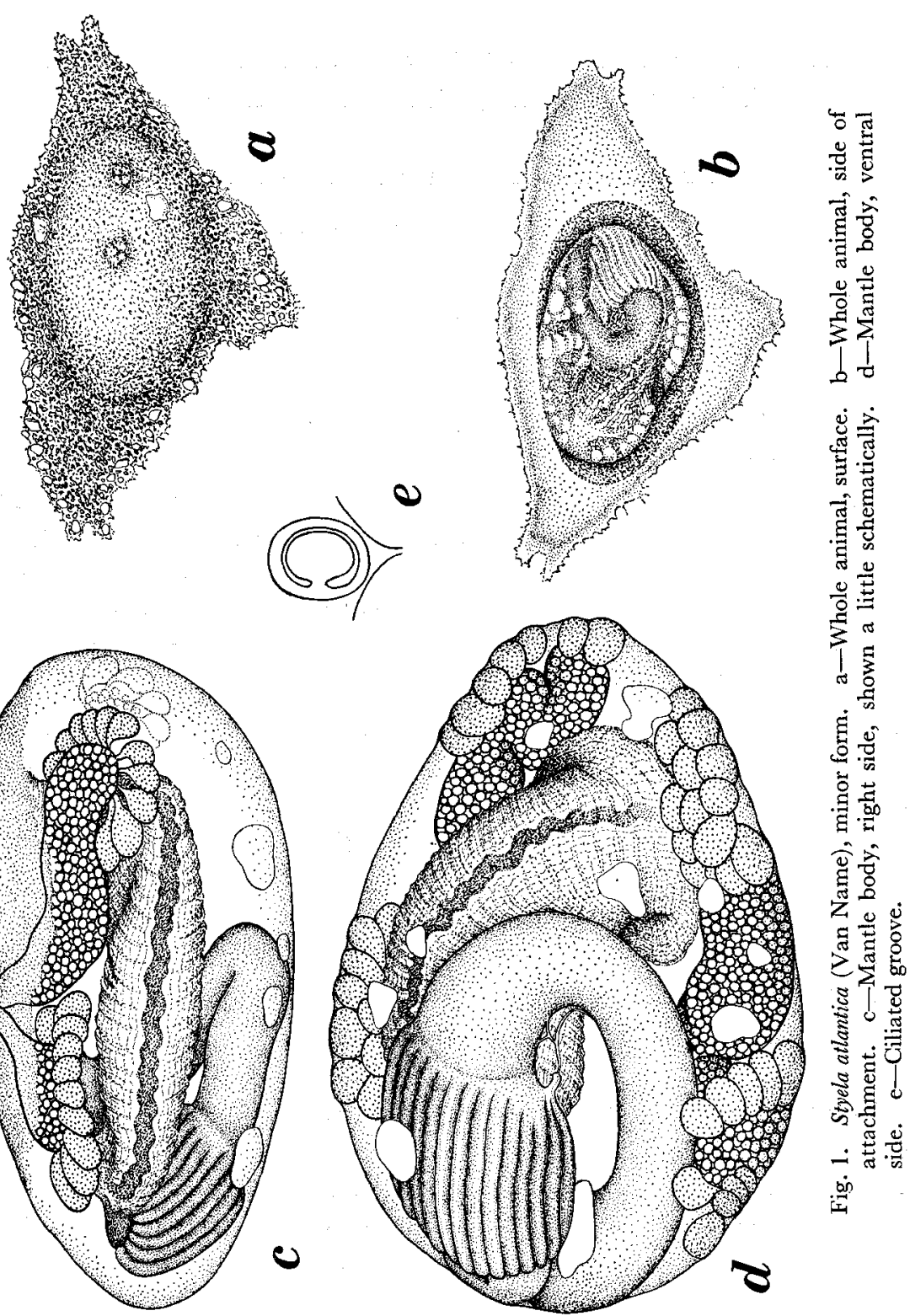

The mantle body (fig. 1 , c and d) is $7 \mathrm{~mm}$ long, $5 \mathrm{~mm}$ wide, and $4 \mathrm{~mm}$ high when it is taken out of the test. The space between the test and the mantle body is filled with a very loose tissue. The mantle is of a moderate thickness only around the dorsal siphonal area, but extremely thin in other parts. The branchial siphon is subterminal, short and 4-lobed, the atrial is situated approximately at the middle on the dorsal side, 4-lobed and completely sessile. Atrial filaments are very fine and slender. There are a considerable number of endocarps over the inner surface of the mantle, some of larger ones are coloured somewhat darker. 
The branchial sac is rather shrunk, this might be caused by parasitism of a copepod in the peribranchial cavity. Four folds are defined clearly on each side of the sac. Inner longitudinal vessels are arranged as follows:
Left
D. 3
(16) 1
(9) 0
0
(3) $0 \mathrm{~V}$.
Right
D. 0 (10) 1
(9)
(10) 2
(3) $0 \mathrm{~V}$.

The dorsal lamina is very high. Stigmatal rows are seemingly very limited, and therefore stigmata are very long; thicker and thinner transverse vessels alternate regularly. Tentacles are rather large, about 15 excluding smaller ones. The ciliated groove is $\mathrm{C}$-shaped (fig. 1, e).

The anterior end of the intestinal loop (fig. 1, d) reaches about the middle of the body. The stomach occupies more than a half of the ventral branch of the loop and is furnished with about 30 longitudinal plications. A small but distinct pyloric coecum is present. The axis of the second loop passes seemingly the cardiac end of the stomach. The anus is divided into several lobes. A pair of gonads on each side. Tubular ovaries are undulating, though less on the left side. The testis is confined to the posterior part of each gonad, testicular follicles are 17 in the anterior gonad and 10 in the posterior one on the left side, while 13 and 10 in the anterior and posterior gonads respectively on the right side.

Remarks: Five to $15 \mathrm{~mm}$ long, more or less dorso-ventrally flattened individuals of Styela atlantica, that were found attached to the deep-water forms of Herdmania momus (Savigny) collected at Albatross Sta. 3698 off Manazuru-Zaki in Sagami Bay, have been described already (Tokioka 1967, fig. 83e). In these, the test is very thin, encrusted and impregnated with mud, and both apertures open on the dorsal side. In a $13 \mathrm{~mm}$ long individual of these, the arrangement of the inner longitudinal vessels of the branchial sac is as follows (p. 192):

$\begin{array}{llllllllllll}\text { Left } & \text { D. } & 2 & (11) & 5 & (12) & 4 & (17) & 5 & (11) & 2 & \text { V. } \\ \text { Right } & \text { D. } & 4 & (22) & 4 & (12) & 4 & (16) & 5 & (9) & 2 & \text { V. }\end{array}$

The present specimen from a holothurian resembles these in the general appearance of the body and the internal structure, especially closely in those of the alimentary canal and the gonad. Existence of many endocarps is also common to both the albatross specimens and the present one. Tentacles are 27 in that $13 \mathrm{~mm}$ long Albatross specimen, but in this case larger to smaller ones are included. The anal margin is divided into 15 lobules in the Albatross specimen, but this is of minor significance, as the subdivision of anal lobes may occur rather generally. Possible significant differences may be found in the shape of the ciliated groove which is a simple opening in that Albatross specimen and in the site of the largest branchial fold. In that Albatross specimen, the first right fold is the greatest, while in the present specimen the first left fold is most developed. Probably this feature in the present specimen is related with the development of the dorsal lamina, and these might be attributed to the parasitism of a copepod in the peribranchial cavity, that is clearly of a significant size for the present small ascidian. 
Thus, if the difference in the appearance of the ciliated groove can be put aside at present, the present specimen may safely be identified with the minor form of Styela atlantica. The reduction of the test consistency and impregnation of the test with sand grains or mud are known in other simple ascidians, too, such as Cnemidocarpa fertilis (Hartmeyer) (Tokioka 1967, p. 193; see also C. fertilis f. molguloides, Tokioka 1953). Styela eurygaster Millar from the $60 \mathrm{~m}$ deep off Saldanha on the Brazilian coast somewhat resembles the present specimen in its flattened body shape. The test is smooth, thin, translucent and paper-like, though not impregnated with sand. However, this Brazilian species is provided with 2 and 4 branchial folds on the left and right sides respectively, and with 1 and 2 gonads on the left and right sides respectively. Of these differences, that in the distribution of gonads might be of minor significance, as the elimination of one of the two gonads at a significant rate on one or both sides is reported in S. atlantica (Monniot 1969, p. 172). Further, the reduction of some branchial folds is suggested by Millar (1977) in some species. Therefore, $S$. eurygaster itself might represent a special individual or form of $S$. atlantica.

Especially, the reduction of the body size in the present specimen, if the identification here proposed is accepted, reminds us of a dwarf-form of Capulus ungaricus (L.), a prosobranch generally commensalistic on bivalves, that is produced by unusual living on a gastropod, Turritella communis Risso in the Danish waters (Thorson 1965). Probably unusual substratum on the holothurian body wall has brought about in the present specimen the suppression of the body size and the modification of the body shape, and the parasitism of a copepod in the peribranchial cavity some special internal feature.

Before closing this short note, we wish heartily to express our cordial thanks to Mr. Imaoka for his generosity in submitting the present interesting specimen and important information to us.

\section{REFERENCES}

Millar, R.H. 1971. The biology of ascidians. Adv. mar. Biol., vol. 9, 100 pp.

1977. Ascidians (Tunicata: Ascidiacea) from the northern and north-eastern Brazilian Shelf. Jour. Nat. Hist., vol. 11, no. 2, pp. 169-223.

Monniot, C. 1969. Ascidies récoltées par la "Thalassa" sur la pente du plateau continental du Golfe de Gascogne (3-12 août 1967). Bull. Mus. Nation. Hist. Nat. Paris, 2e Ser., vol. 41. no. 1, pp. $155-186$.

- 1974. Ascidies littorales et bathyales récoltées au cours de la campagne Biaçores: Phlebobranches et Solidobranches. Bull. Mus. Nation. Hist. Nat., 3e Ser., no. 251, zool. 173, pp. 13271352.

Théel, H. 1886. Report on the Holothuroidea dredged by H.M.S. Challenger during the years 1873-76. Part II. Chall. Rep. Zool., vol. 14.

Thorson, G. 1965. A neotenous dwarf-form of Capulus ungaricus (L.) (Grastropoda, Prosobranchia) commensalistic on Turritella communis Risso. Ophelia, vol. 2, no. 1, pp. 175-210.

Tokioka, T. 1953. Ascidians of Sagami Bay. Iwanami Shoten, Tokyo.

1967. Pacific Tunicata of the United States National Museum. U.S. Nat. Mus. Bull. 251. 